\title{
PEMBALAJARAN DAN PENDAMPINGAN PEMANFAATAN SPSS UNTUK MENINGKATKAN KOMPETENSI OLAH DATA STATISTIK BAGI GURU DI SMA NEGERI 1 KEMUSU BOYOLALI
}

\author{
Wiharto $^{1^{*}}$, Esti Suryani ${ }^{2}$, Umi Salamah ${ }^{3}$, \\ Nurcahya PTP ${ }^{4}$, Sigit Setyawan ${ }^{5}$.
}

Riset Grup Computational Science \& Engineering Universitas Sebelas Maret.

${ }^{1}$ wiharto@staff.uns.ac

2estisuryani@staff.uns.ac.id

33umisalamah@staff.uns.ac.id

${ }^{4}$ nurcahya.ptp@staff.uns.ac.id

${ }^{5}$ sigitsetyawa@staff.uns.ac.id

*correspoinding author

\section{ABSTRAK}

Penulisan karya ilmiah bagi guru merupakan salah satu persyaratan untuk kenaikan pangkat. Hal ini membuat banyak guru kemudian membuat karya ilmiah. Namun banyak yang masih kesulitan dalam rangka naik jabatan fungsional karena beberapa karya ilmiah kurang memenuhi standar, dimana data yang disajikan tidak dapat merepresentasikan keseluruhan isi tulisan. Kemampuan pengolahan dan penyajian data penelitian merupakan faktor penting dalam penulisan karya ilmiah. Guru di SMA Negeri 1 Kemusu merupakan salah satu potret yang mengalami masalah tersebut. Hal inilah yang melatarbelakangi pengabdian menganai pemanfaatan SPPS untuk meningkatkan kompetensi guru dalam mengolah data statistik ini. SPSS (Statistical Package for the Social Sciences) merupakan salah satu aplikasi perangkat lunak komputer yang digunakan untuk analisis statistik. Tujuan dari kegiatan pengabdian kepada masyarakat ini adalah untuk meningkatkan kemampuan guru -guru di SMA Negeri 1 Kemusu dalam melakukan pengolahan data penelitian sebagai data pendukung karya ilmiah. Kegiatan pengabdian dilakukan dalam empat tahap. Tahap pertama adalah identifikasi kemampuan pengolahan data statistik dan identifikasi penentuan materi utama. Tahap kedua adalah pelaksanaan workshop yang diisi dengan turorial pemanfaatan SPSS dalam menyelesaikan masalah statistik. Tahap ketiga adalah simulasi penggunaan SPSS. Tahap keempat adalah evaluasi. Setelah dilakukan evaluasi diperoleh bahwa ada peserta yang sudah mengetahui adanya aplikasi olah data statistik sebanyak $30 \%$ dan setelah diadakan pelatihan SPSS sebanyak $100 \%$ peserta mengetahui dan dapat meningkatkan kemampuan dalam melakukan analisis data statistik. Secara umum ada $70 \%$ peningkatan kemampuan dalam olah data statistik dengan SPSS, meskipun masih banyak kendala yang dihadapi peserta, yaitu kurang terbiasa dan kurang latihan sebanyak $85 \%$.

KATA KUNCI: SPSS, olah data statistik, SMA Kemusu

\section{PENDAHULUAN}

Guru memegang peranan penting dalam rangka mencerdaskan kehidupan bangsa. Oleh sebab itu berbagai kebijakan dan kegiatan telah dan akan terus dilakukan untuk meningkatkan karir, mutu, penghargaan, dan kesejahteraan guru. Harapannya mereka akan lebih mampu bekerja sebagai tenaga profesional dalam melaksanakan tugas dan tanggung jawabnya [1]. Salah satu kebijakan penting adalah kaitannya dengan promosi kenaikan pangkat/jabatan guru dengan prestasi kerja. Prestasi kerja guru tersebut sesuai dengan tupoksinya berada dalam bidang kegiatannya antara lain adalah pendidikan, proses pembelajaran, pengembangan profesi, dan penunjang proses pembelajaran. Keputusan Menteri Pendayagunaan Aparatur Negara Nomor 84/1993 tentang Jabatan Fungsional Guru dan
Pendidikan dan Kebudayaan dan Kepala BAKN Nomor 0433/1993 nomor 25 tahun 1993 tentang Petunjuk Pelaksanaan Jabatan Fungsional Guru dan Angka Kreditnya, pada prinsipnya bertujuan untuk membina karier kepangkatan dan profesionalisme guru. Kebijakan itu diantaranya mewajibkan guru untuk melakukan keempat kegiatan yang menjadi bidang tugasnya, dan hanya bagi mereka yang berhasil melakukan kegiatan dengan baik diberikan angka kredit. Selanjutnya, angka kredit itu dipakai sebagai salah satu persyaratan peningkatan karir. Penggunaan angka kredit (PAK) sebagai salah satu persyaratan seleksi peningkatan karir.

PAK sebagai salah satu persyaratan seleksi peningkatan karir, bertujuan memberikan penghargaan secara lebih adil dan lebih profesional terhadap kenaikan pangkat yang merupakan pengakuan profesi serta kemudian memberikan peningkatan kesejahteraanya. Sebagai tindak 
lanjutnya adalah guru dituntut dari berbagai pihak untuk dapat melaksanakan Penelitian Tindakan Kelas (PTK) [2]. PTK Penelitian Tindakan Kelas ini tentunya membutuhkan sarana dan prasarana yang bisa membantu dan memudahkan dalam pelaksanaannya. Salah satunya adalah penggunaan teknologi informasi. Pemanfaatan software yang sederhana seperti Microsoft Word, schoology, mendeley, zotero dan sebagainya belum bisa dimanfaatkan secara optimal. Banyak guru yang belum memahami dan mengoptimalkan fungsi dari menu-menu pada software tersebut. Padahal software tersebut sangat membantu mempermudah pelaksanaan PTK. Berdasarkan analisis situasi sebanyak sekitar $80 \%$ dari jumlah total guru di beberapa sekolah belum mengerti dan memahami fungsi dari menu-menu yang ada pada software tersebut.

Tuntutan tersebut terkait dengan kebutuhan akreditasi sekolah, kenaikan pangkat, program BOS (Bantuan Operasional Sekolah) dan sertifikasi sebagai pendidik. Tuntutan tersebut pada satu sisi mendorong para guru untuk berusaha melaksanakan penelitian di sekolahnya demi memenuhi tuntutan, namun tak sedikit guru-guru yang putus asa karena tidak dapat melaksanakan kegiatan tersebut. Pada hal kebutuhan tersebut menjadi salah satu syarat penentu untuk dapat tidaknya seorang guru yang sudah berpangkat Pembina (IVA) naik ke jenjang yang lebih tinggi. Keresahan yang dialami oleh para guru pada satu sisi mendorong upaya positif para guru untuk mau belajar dan meneliti secara wajar demi mendapatkan Kredit Poin untuk dapat naik pangkat ke jenjang lebih tinggi, namun ada sebagian guru yang memilih jalan pintas dengan memesan karya ilmiah pada pihak-pihak tertentu. Dampaknya, citra guru tercoreng dengan munculnya PAK palsu. Kejadian yang mencoreng citra sebagian guru tersebut sebenarnya tidak perlu terjadi jika para penentu kebijakan baik swasta maupun negeri mau dengan sungguh-sungguh memperhatikan kebutuhan guru dalam mengembangkan kemampuan menulis karya ilmiah di antaranya PTK [3].

Bagi guru yang masih memiliki motivasi untuk medapatkan naik pangkat ke golongan lebih tinggi setelah IV/a atau menambah skor portofolio dalam sertifikasi guru dalam jabatan adalah adanya keinginan untuk menulis. Motivasi menjadi faktor penentu dari kelanjutan untuk mewujudkan keinginan tersebut. Seperti yang disebutkan dalam SK Menpan No. 84/1993 tanggal 24 Desember 1993 tentang jabatan fungsional guru dan angka kreditnya, bahwa untuk kenaikan pangkat/jabatan yang lebih tinggi dari Pembina/IVa menjadi
Pembina Tingkat I /IVb atau tingkatan yang lebih tinggi lagi diwajibkan sekurang-kurangnya 12 angka kredit unsur pengembangan profesi. Jika butir ini tidak dipenuhi, maka pangkat guru akan mentok sampai golongan IV/a [4].

Beberapa sekolah di Kabupaten Boyolali mengalami permasalahan tersebut. Salah satu sekolah di Kabupaten Boyolali yang memiliki keadaan yang sama dengan uraian di atas adalah seperti SMA Negeri 1 Kemusu. Permasalahan yang dominan muncul adalah kebanyakan guru akan mengajukan kepangkatan tetapi terkendala dalam penulisan artikel, penggalian ide, dan mengolah data. Faktor penghambat penulisan artikel tersebut antara lain karena sulitnya menyajikan data dalam bentuk yang efektif dan efisien. Teknik pengolahan data, terutama untuk statistik, masih mengalami hambatan karena kurangnya kemampuan menggunakan alat bantu perhitungan data.

Berdasarkan wawancara yang telah dilakukan oleh pengusul dan Kepala Sekolah SMA Negeri 1 Kemusu, sebagian besar guru mengalami hambatan dalam melakukan pengolahan dan penyajian data. Mereka belum mahir dalam pemanfaatan teknologi informasi untuk mempermudah pengerjaaanya. Teknologi informasi yang dapat dioptimalkan untuk pengolahan antara lain adalah penggunaan perangkat lunak SPSS.

\section{METODE}

Tahapan yang akan dilaksanakan secara detail dalam kegiatan pemanfaatan SPSS untuk pemgolahan data statistik dalam Program Pengabdian melalui Pembelajaran dan Pendampingan SPSS untuk Guru SMA Negeri 1 Kemusu Boyolali antara lain:

1. Tahap pertama adalah survey dan studi analisis situasi SMA Negeri 1 Kemusu Boyolali. Kegiatan ini meliputi pendataan jumlah guru, mendata golongan/pangkat, mendata jumlah artikel yang sudah dihasilkan, mendata aktifitas metode pembelajaran yang sering dilakukan oleh guru, dan data lain untuk mendukung keberjalanan Program Pelatihan dan Pendampingan SPSS. Pada tahap ini dilakukan oleh Tim Pengabdian HGR dari kepakaran bidang Teknik Informatika untuk membantu dalam mendata maupun menggali permasalahan.

2. Tahap kedua adalah workshop penggunaan SPSS sebagai alat bantu pengolahan data penelitian. Pada tahap ini dijelaskan tentang optimalisasi penggunaan menu-menu yang ada pada program SPSS. 
3. Tahap ketiga adalah edukasi dan pendampingan penggunaan SPSS secara privat. Pada tahap ini guru SMA mitra diberikan tugas untuk dapat membuat dan menampilkan data hasil olahan data satistik. Selanjutnya guruguru tersebut akan diberikan edukasi dan pendampingan secara privat berupa review terhadap hasil tugas yang telah dikerjakan. Guru pada SMA mitra juga dapat melakukan konsultasi berbagai kendala dalam penggunaan aplikasi SPSS dengan tim Pengabdian. Hal ini dilakukan berkala selama beberapa kali, baik daring atau luring agar menghasilkan luaran yang diharapkan.

4. Tahap keempat adalah pemantauan dan evaluasi berkala kegiatan Program Pembelajaran dan Pendampingan SPSS. Pada tahap ini selain dilakukan pemantauan juga dilakukan evaluasi keberhasilan Program Pembelajaran dan Pendampingan SPSS.

\section{HASIL DAN PEMBAHASAN}

Pelaksanaan pengabdian dilakukan dalam beberapa tahap yang secara keseluruhan tahapan pengabdian dapat ditunjukkan pada Tabel 1

Tabel 1. Tahapan pelatihan pemanfaatan SPSS

\begin{tabular}{cl} 
Tahap & \multicolumn{1}{c}{ Topik } \\
\hline 1 & Proses Instalasi, pengenalan SPSS \\
2 & Variabel-variabel SPSS, Import export database \\
3 & Penugasan, pendalaman materi ke-2 \\
4 & Statistik deskriptif \\
5 & Penugasan, pendalaman materi ke-4 \\
6 & Penyajian data dalam bentuk diagram \\
7 & Penugasan, pendalaman materi \\
8 & Analisis Inferensi: Uji T one sample \\
9 & Penugasan, pendalaman materi ke-8 \\
10 & Analisis Inferensi: Uji T sample berpasangan \\
\hline
\end{tabular}

Pelaksanaan pengabdian dilakukan dalam beberapa tahap yang secara keseluruhan tahapan pengabdian dapat ditunjukkan pada Tabel 1. Tahapan pembelajaran dilaksanakan setiap seminggu satu kali mulai tanggal 29 Agustus 2020 sampai dengan 07 November 2020. Peserta pelatihan SPSS ini diikuti oleh 21 peserta. Tahap pertama yaitu proses instalasi, dalam hal ini yang diisntal adalah SPSS 25. Kemudian dilanjutkan dengan pengenalan SPSS berupa variabel-variabel dalam SPSS, input data daam SPSS dan import dan export database, dalam hal ini import file excel ke SPSS, dan export file SPSS ke excel. Gambar 1 berikut merupakan tahapan membuka editor dalam SPSS.
Pelaksanaan pengabdian dilakukan dalam beberapa tahap yang secara keseluruhan tahapan pengabdian dapat ditunjukkan pada Tabel 1. Pada Gambar 1 Data View untuk input data, dan Variabel View untuk mendefinisikan variabel-variabel yang akan digunakan.

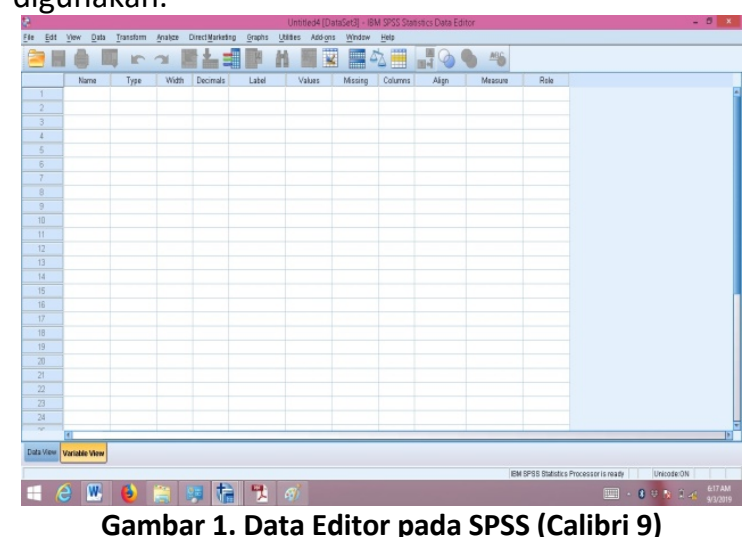

Tahap selanjutnya yaitu latihan SPSS untuk input data. Keterangan pada Variabel View.

o Name digunakan untuk memberi keterangan nama variabel

- Type untuk memilih jenis data yang direkam

o Width untuk mengatur lebar kolom dalam hasil analisis

- Decimal digunakan untuk menentukan jumlah angka di belakang koma

- Label digunakan untuk memberikan keterangan pada variabel

- Value digunakan untuk memberikan keterangan untuk data variabel

- Missing digunakan untuk mengatur data hilang/tidak lengkap

- Column digunakan untuk mengatur lebar kolom dalam data view

- Align digunakan untuk mengatur jenis perataan

- Measure digunakan untuk menentukan jenis skala pengukuran data

Tabel 2 berikut ini merupakan contoh soal yang digunakan untuk input data SPSS, yang digunakan untuk pelatihan.

Tabel 2. Contohsoal untuk input data SPSS

\begin{tabular}{ccc}
\hline NAMA & NILAI & GENDER \\
\hline Agus & 65 & PRIA \\
Budi & 68 & PRIA \\
Cucu & 50 & WANITA \\
Didi & 65 & PRIA \\
Emi & 58 & WANITA \\
Fandi & 61 & PRIA \\
Kania & 69 & WANITA \\
Gani & 61 & PRIA \\
\hline
\end{tabular}


Pada kasus Soal Tabel 2 di atas terdiri atas tiga variabel, yakni Nama, Nilai, dan Gender. Untuk itu, akan dilakukan input tiga variabel di atas: Setelah dibuka SPSS akan aktif SPSS Editor (pada Gambar 1 di atas), kemudian pada bagian kiri bawah dari tampilan di atas ada Data View dan Variable View. Klik tab VARIABLE VIEW kemudian diinputkan variabel sehingga diperoleh hasil seperti pada Gambar 2 di bawah ini.

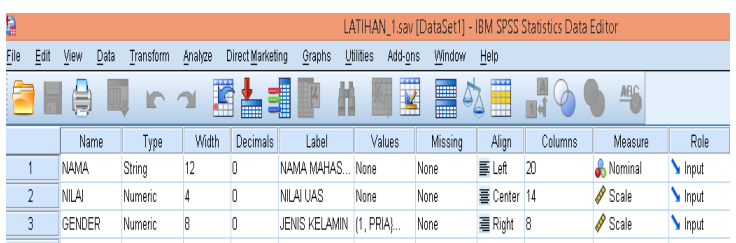

Gambar 2. Pendefinisian variabel pada SPSS dengan contoh kasus di Tabel 2 (Calibri 9)

Setelah selesai mendefiniskan varibel Nama, Nilai dan Gender, selanjutnya kita akan menginputkan datanya pada "Data View", diperoleh tampilan seperti pada Gambar 3. Selanjutya disimpan ke dalam file SPSS. Setelah itu untuk menggunakan SPSS untuk proses import yaitu dengan membuka file excel melalui SPSS kemudian disimpan ke dalam format SPSS.

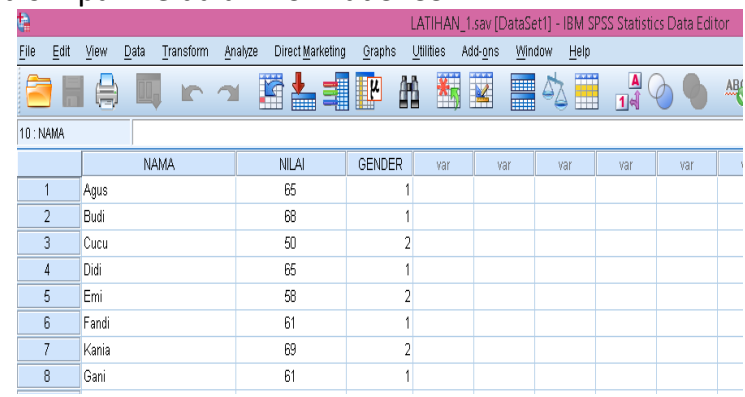

Gambar 3. Input data di Data View editor

Pelaksanaan kegiatan yang kedua, berupa penyampaian materi dan pendampingan yang dilkukan oleh tim pengabdian denan cara mereview tugas mandiri yang diberikan kepada para peserta pelatihan SPSS. Tugas mandiri yang diberikan bertujuan untuk memperdalam pemahaman terhadap materi pelatihan yang telah disampaikan. Pendampingan berupa review atau umpan balik terhadap tugas yang dikerjakan oleh peserta pelatihan yang dikumpulkan dalam bentuk file melalui media google classroom yang telah disediakan oleh tim pengabdian. Dlam hal ini tim pengabdian sebagai teacher dan peserta pelatihan sebagai student. Materi yang diapload oleh tim pengabdian di dalam google classroom berupa modul materi, video materi, dan penugasan bagi para peserta. Berikut Gambar 4 adalah materi yang disampaikan dan penugasan untuk pendalaman materi yang disampaikan melalui google classroom untuk menunjang pelaksanaan pengabdian pelatihan SPSS. Materi disampaikan dengan melakukan workshop dan memberikan contoh pengaplikasian ke dalam SPSS yang diikuti oleh seluruh peserta.

Materi

\begin{tabular}{|c|c|}
\hline (1) Mocul Materispss & EAted Sep $4 \quad:$ \\
\hline (D) Instalasi SPSS & Edted Sep $4 \quad \vdots$ \\
\hline (4) Uij Tample berpasangan & Edted Sep $4 \quad \vdots$ \\
\hline (ㄷ) sPsS untuk Uij & Edted Sep $4 \quad \vdots$ \\
\hline (ㄴ) Penyaijin data dalam bentuk diagram & Edted Sep $4 \quad \vdots$ \\
\hline (4) SPSS untuk statsitik sederhana :Statistik des... & Eetted Sep 4 : \\
\hline () Pengenalan SFSS Variabel-verizbel dalam SP... & Etred Sep A $\quad \vdots$ \\
\hline
\end{tabular}

Gambar 4. Input Materi yang diapload di Google Classroom

Selanjutnya peserta diberikan penugasan mengenai materi untuk pendalaman penguasaan materi. Contoh penugasan dapan ditunjukkan pada Gambar 5.

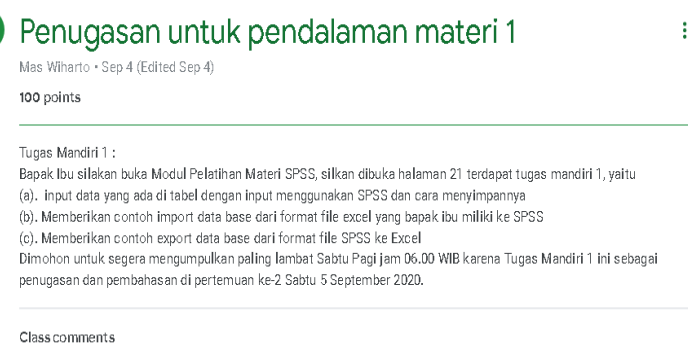

Gambar 5. Contoh penugasan di google classroom

Pengiriman tugas yang dilakukan oleh para peserta di google classroom dapat ditunjukkan pada Gambar 6. Kemudian tugas yang telah dikirimkan peserta direview dan diberikan feetback oleh tim pengabdi.

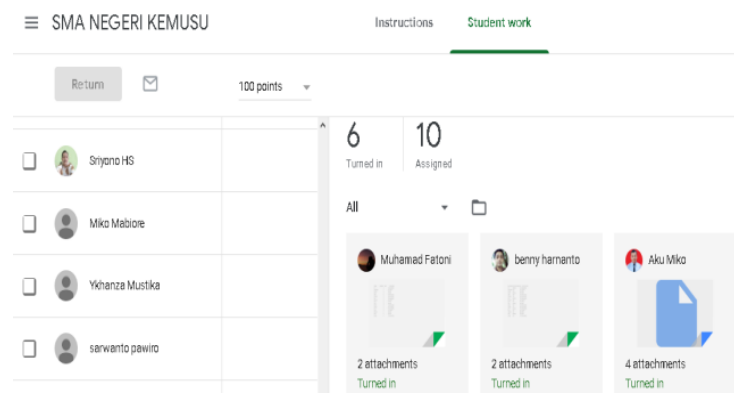

Gambar 6. Contoh pengiriman tugas Mandiri peserta pelatihan SPSS ke google classroom 
Sebagai proses evaluasi dari pendampingan dan pelatihan SPSS yang telah diselenggarakan peserta diberikan kuisioner atau pengisian angket melalui google classroom. Kuisioner diberikan untuk mengetahui apakah ada peningkatan pengetahuan dan keterampilan analisis data para peserta pelatihan atau tidak. Berikut ini Tabel 3 merupakan tabel pertanyaan pada kuisioner atau angket dan jawaban dari para peserta pengabdian sebagai bahan untuk evaluasi dapat ditunjukkan pada Tabel 4. Kuisioner dibagikan kepada seluruh peserta pelatihan SPSS, sedangkan yang mengisi kuisioner ada 10 peserta dari 21 peserta.

Tabel 3. Pertanyaan pada angket (kuisioner) untuk evaluasi

\begin{tabular}{ll}
\hline No & \multicolumn{1}{c}{ Pertanyaan } \\
\hline 1 & $\begin{array}{l}\text { Apakah Anda Tahu aplikasi olah data } \\
\text { Statistik SPSS, sebelum pelatihan? }\end{array}$ \\
2 & $\begin{array}{l}\text { Apakah Anda pernah menggunakan aplikasi } \\
\text { olah data Statistika sebelum pelatihan SPSS? }\end{array}$ \\
3 & $\begin{array}{l}\text { Menurut Anda apakah pelatihan } \\
\text { penggunaan olah data statistika SPSS ini } \\
\text { diperlukan? }\end{array}$ \\
4 & $\begin{array}{l}\text { Apakah Anda kesulitan dalam mengolah } \\
\text { data sebelum diadakan pelatihan SPSS? }\end{array}$ \\
Apakah Anda pernah melakukan analisis \\
statistika sederhana (rata-rata, mean, \\
median, modus, dan membuat grafik) \\
sebelum pelatihan SPSS? \\
Setelah mengikuti pelatihan SPSS apakah \\
menurut Anda ada peningkatan \\
pengetahuan dan kemudahan analisis \\
statistika sederhana dengan Aplikasi SPSS? \\
Apakah sebelum ada pelatihan SPSS Anda \\
sudah mengetahui cara uji normalitas data?
\end{tabular}

13 Apakah Anda mengalami kendala atau kesulitan pada saat melakukan uji $t$ One Sample atau paired dengan menggunakan SPSS?

14 Apakah dengan adanya pelatihan SPSS ini dapat meningkatkan kemampuan analisis dan kemudahan Anda dalam melakukan perhitungan dan analisis data statistik?

Jawaban dari pertanyaan yang disampaikan pada Tabel 3 dapat ditunjukkan pada Tabel 4.

Table 4. Jawaban kuisioner pada pertanyaan tabel 3

\begin{tabular}{|c|c|c|}
\hline \multirow{2}{*}{$\begin{array}{c}\text { No } \\
\text { pertanyaan }\end{array}$} & \multicolumn{2}{|c|}{ Jawaban } \\
\hline & Ya (\%) & Tidak (\%) \\
\hline 1 & 30 & 70 \\
\hline 2 & 20 & 80 \\
\hline 3 & 100 & 0 \\
\hline 4 & 10 & 90 \\
\hline 5 & 60 & 40 \\
\hline 6 & 100 & 0 \\
\hline 7 & 30 & 70 \\
\hline 8 & 10 & 90 \\
\hline 9 & 100 & 0 \\
\hline 10 & 80 & 20 \\
\hline 11 & 30 & 70 \\
\hline 12 & 90 & 10 \\
\hline 13 & 80 & 20 \\
\hline 14 & 30 & 70 \\
\hline
\end{tabular}

Sebelum dilakukan evaluasi peserta juga diberikan pelatihan mengenai analisis statistik deskriptif yang antara lain dibahas mengenai mean, median, frekuesi, standar deviasi, penyajian analisis dalam bentuk diagram. Pelatihan dilanjutkan dengan uji kenormalan data melihat apakah data terdistribusi normal atau tidak. Data yang terdistribusi normal akan memperkecil terjadinya bias. Ada dua jenis uji normalitas data yang diberikan pada pelatihan ini yaitu Kolmogorov-Smirnov dan Shapiro-Wilk. Pada akhir pelatihan diberikan uji One Sample t. Test dan Paired sample t test merupakan uji beda sampel berpasangan. Selain melakukan workshop para peserta pelatihan juga diberikan tugas untuk 
pendalaman materi, di setiap materi yang diberikan kemudian direview oleh tim pengabdi. Berdasarkan Tabel 4 para peserta sebanyak 30\% telah mengetahui adanya aplikasi olah data statistik SPSS ini dan dari $30 \%$ tersebut $20 \%$ di antaranya pernah menggunakan olah data dengan SPSS. Secara umum sebelum mengukuti pelatihan SPSS para peserta mengalami kesulitan dalam olah data statistik sebanyak $10 \%$ dan dengan menggunakan SPSS ini dan sebanyak $90 \%$ mengalami kemudahan dalam menggunakan SPSS. Namun masih banyak kendala yang dirasakan oleh para peserta dalam penggunaan SPSS untuk olah data ini sebanyak $85 \%$ pada uji normal dan uji t. Kendala tersebut dapat disebabkan karena para peserta kurang terbiasa melakukan uji statistik khususnya uji kenormalan data dan uji t, dikarenakan sebagian besar jika para guru melakukan analisis tindakan kelas cukup sampai pada analisis statistik deskriptif. Uji kenormalan data dan uji t sangat jarang digunakan. Penyebab yang lain adalah kurangnya latihan olah data, itu dapat terlihat dari penugasan yang diberikan dengan tujuan untuk memperdalam dan meningkatkan kemampuan uji statisktik dengan SPSS, namun yang mengerjakan penugasan ratarata $46 \%$ dari peserta yang mengerjakan penugasan dengan baik. Namun para peserta juga sangat antusias dengan perlua adanya pelatihan SPSS yaitu sebanyak 100\%. Pelatihan SPSS ini juga secara umum dapat meningkatkan pengetahuan dan kemudahan dalam melakukan olah data statistik sebanyak $100 \%$, meskipun masih banyak kendala yang dihadapi.

\section{KESIMPULAN}

Pendampingan dan pelatihan SPSS bagi para guru khususnya guru SMU 1 Kemusu Boyolali secara umum dapat meningkatkan pengetahuan dan kekampuan peserta dalam melakukan olah data statistik. Sebelumnya dilakukan pelatihan telah ada peserta yang mengetahui adanya aplikasi olah data statistik sebanyak $30 \%$ dan setelah diadakan pelatihan SPSS $100 \%$ dari peserta mengetahui dan dapat meningkatkan kemampuan peserta dalam melakukan analisis data statistik dengan menggunakan SPSS, ini berarti secara umum ada 70\% peningkatan kemampuan dalam olah data statistiK dengan menggunakan SPSS, meskipun masih banyak kendala yang dihadapi oleh peserta, terutama masih kurang terbiasa dan kurang latihan yaitu sebanyak $85 \%$.

\section{DAFTAR PUSTAKA}

[1] E. Widoyoko, "Penelitian Tindakan Kelas Dan Pengembangan Profesi Guru", Seminar Nasional Peningkatan Kualitas Profesi Guru Melalui Penelitian Tindakan Kelas, September 2008.

[2]. W. Darmalaksana, " Panduan Publikasi Ilmiah : Perangkat Aplikasi, Standar Penulisan dan Etika Kepengarangan", J. Ris. Dan Inov., vol. 2, p. November, 2017.

[3]. E. Widoyoko , "Perananan Sertifikasi Guru Dalam Meningkatkan Mutu Pendidikan", Seminar Nasional Peningkatan Kualitas Profesi Guru Melalui Penelitian Tindakan Kelas, Juli 2008.

[4] S. Alam, "Penulisan Artikel Ilmiah untuk Publikasi Ilmiah Melalui Jurnal", Artik. E-Bul., pp. 355-389. 2015. 